\title{
KAMPANYE EDUKASI KESEHATAN MENTAL IG @ healthy_mind BAGI MAHASISWA JABODETABEK DI MASA PANDEMI COVID -19
}

\author{
Richard Omar Widjaya, \\ Marshella Erna, \\ Agustin Diana Wardaningsih \\ ${ }^{1}$ Universitas Pelita Harapan \\ ${ }^{2}$ Universitas Pelita Harapan \\ ${ }^{3}$ Universitas Pelita Harapan
}

Richardomarwidjaja99999@gmail.com, marshellaernaa@gmail.com, agustin.wardaningsih@uph.edu

\begin{abstract}
Abstrak
Komunikasi juga dibutuhkan untuk memberikan informasi positif, membangun kesadaran dan pola pikir kritis. Salah satunya lewat cara Kampanye untuk mempersuasi dan mengedukasi dalam melakukan hal yang postitif. Merebaknya Pandemi Covid - 19, membawa perubahan baru dalam kehidupan masyarakat. Adanya pembatasan interaksi dan himbauan untuk 'stay at home' memunculkan salah satunya masalah kesehatan mental. Untuk itu dilakukan kegiatan kampanye kesehatan mental melalui Instagram @ healthy_mind dengan tujuan untuk memberikan edukasi, mensosialisasikan kepada masyarakat khususnya mahasiswa usia $18-23$ tahun yang perlu mendapatkan pemahaman yang tepat tentang Kesehatan mental.

Yang dilakukan selama kampanye pada bulan Mei hingga Juli 2020 adalah dengan membuat postingan terkait ganguan kesehatan mental dan cara menanganinya, memberikan muatan pesan postif agar penderita belajar untuk terbuka dan mencari bantuan. Selain itu dengan mengadakan webinar serta dialog liveIG, sehingga pesan secara terus menerus bisa diterima dengan baik. Dengan demikian Kampanye bisa berjalan dengan baik dan memberikan hasil yang sesuai.
\end{abstract}

Kata Kunci: Komunikasi, Kampanye, Edukasi, kesehatan mental, Pandemi Covid-19

\section{PENDAHULUAN}

Komunikasi adalah sebuah proses mengirimkan pesan dan menerima feedback dari pesan tersebut. Kemampuan berkomunikasi yang baik membantu kita untuk bisa berinteraksi dalam sebuah lingkungan sosial. Komunikasi juga digunakan untuk menyampaikan pesan positif, mengedukasi masyarakat, dan membuka wawasan pikir agar masyarakat bisa memahami sebuah informasi dengan tepat \& kritis. Salah satunya terkait dengan informasi seputar kesehatan mental. 
Kesehatan mental merupakan hal yang penting untuk diperhatikan dalam kehidupan manusia. Putri, Wibawa, Gutama ( 2015) menyebutkan bahwa gangguan Kesehatan mental merupakan kondisi dimana seorang individu mengalami kesulitan dalam menyesuaikan dirinya dengan kondisi di sekitarnya.

Pandemi Covid-19 telah membuat banyak orang merasa ketakutan atau cemas secara terus menerus karena jumlah kasus positif Covid-19 terus bertambah setiap harinya, dan hal ini mengharuskan setiap individu untuk melakukan karantina di rumah masing-masing, sehingga aktivitas sehari-hari pun terhambat yang pada akhirnya menimbulkan kejenuhan pada setiap individu. Selain itu, pandemi Covid-19 mengakibatkan banyak orang kehilangan pekerjaan karena perusahaan tempat mereka bekerja pun mengalami krisis, sehingga banyak orang merasa stres karena mereka terancam tidak bisa memenuhi pengeluaran untuk kebutuhan sehari-hari mereka. Hal-hal tersebut menyebabkan banyak orang merasa stres, cemas, gelisah, ketakutan dan gejala gangguan mental lainnya yang pada akhirnya mempengaruhi tingkat kesehatan mental, yang mengalami penurunan.

Pandemi Covid 19 yang menyebabkan perubahan besar dalam interaksi antar manusia, membuat banyak orang sulit menyesuaikan diri dengan kondisi di sekitar nya sehingga mulai timbul tanda awal gangguan mental. Gangguan kesehatan mental yang terjadi selama pandemi dapat disebabkan oleh berbagai hal, seperti ketakutan terhadap wabah, rasa terasing selama menjalani karantina, kesedihan dan kesepian karena jauh dari keluarga atau orang yang dikasihi, kecemasan akan kebutuhan hidup sehari-hari, ditambah lagi kebingungan akibat informasi yang simpang siur(Nadhira,2020).

Survei singkat dan sederhana menggunakan media sosial yang dilakukan selama satu minggu pada tanggal 23-29 Mei 2020 kepada sekitar 109 orang (18-26 tahun) mengenai "Kesehatan Mental Di Masa Pandemi Covid-19", terdapat 36.7\% responden yang merasa keadaan mentalnya lebih buruk sekarang dibandingkan sebelum terjadinya pandemi Covid-19. Para responden tersebut merasa stres, lelah, cemas atau gelisah, bosan dan lainnya. Alasan mereka merasa seperti itu karena stres mendengarkan berita buruk mengenai penyebaran Covid-19 yang terus bertambah di Indonesia, jenuh karena hanya bisa di rumah \& tidak dapat bertemu dengan orang lain seperti teman-teman, sahabat atau

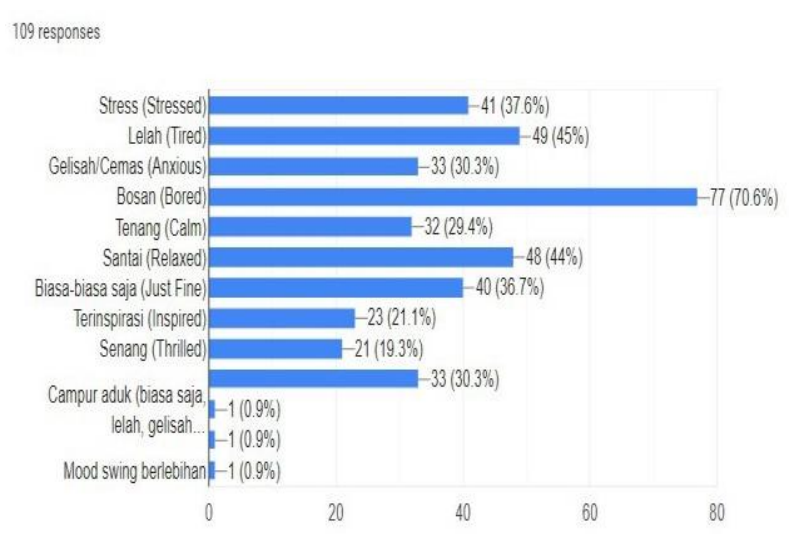

pacar, tugas dan jadwal kuliah yang lebih padat dari sebelumnya, dll. Hasil survei singkat tersebut menjadi salah satu bukti bahwa pandemi Covid-19 telah mempengaruhi kesehatan mental orang usia 1826 tahun yang sebagian besar berada di Jakarta dan Tangerang. Nasution (2020) menyatakan bahwa jumlah orang yang mengalami gangguan kesehatan mental jauh lebih besar daripada orang yang terkena infeksi pada masa wabah.

Gambar 1. Grafik survei “Kesehatan Mental Di Masa Pandemi Covid-19"

Bukan hanya Kesehatan fisik saja yang perlu dijaga tetapi juga Kesehatan mental. Perlu pemahaman yang jelas tentang definisi gangguan mental ini. Florencia (2020) menyatakan bahwa gangguan mental adalah salah satu jenis gangguan pada seseorang yang dapat memengaruhi cara berpikir, memengaruhi emosi, dan tingkah laku pengidapnya.

Ciri-ciri orang yang mengalami sakit jiwa dapat berbeda-beda tergantung dari jenisnya. Kevin (2018) menyebutkan pada umumnya, orang yang mengalami gangguan jiwa dapat dikenali dari beberapa gejala tertentu, suasana hati yang berubah sangat drastis dari sangat sedih menjadi sangat gembira atau sebaliknya, ketakutan berlebih bahkan menarik diri dari kehidupan sosial, kerap merasa sangat marah hingga suka melakukan kekerasan, 
serta mengalami delusional. Bahkan tak jarang gejala tersebut juga diiringi oleh gangguan fisik, seperti sakit kepala, nyeri punggung, sakit perut, atau nyeri lain yang tidak dapat dijelaskan.

Data Riskesdas tahun 2007, diketahui bahwa prevalensi gangguan mental emosional seperti gangguan kecemasan dan depresi sebesar 11,6\% dari populasi orang dewasa. Dengan jumlah populasi orang dewasa Indonesia sekitar 150 juta maka ada sekitar 1.740 .000 orang yang mengalami gangguan mental (Data Depkes pada Putri, Wibawa, Gutama, 2015). Jumlah yang besar, tetapi banyak orang belum memiliki kesadaran tinggi tentang pentingnya mengetahui tentang kesehatan mental. Bahkan penderita gangguan mental pun enggan untuk terbuka untuk mencari bantuan sejak awal dan mendapatkan pengobatan rutin.

Saat ini masih banyak stigma negatif dan diskriminasi terkait orang dengan gangguan mental. Di Indonesia, masih banyak terjadi pengucilan, perlakukan yang salah, sampai pemasungan jika diketahui salah satu anggota keluarga mengalami gangguan mental. Ini yang menyebabkan banyak orang enggan untuk berobat, atau mencari bantuan saat mengalami gangguan mental. Juga terjadi pada anak muda usia 18 - 23 tahun yang akhirnya bukan mencari bantuan tetapi justru mengambil jalan pintas mengakhiri hidup. Putri, Wibawa, Gutama ( 2015) menyebutkan bahwa penderita gangguan Kesehatan mental di berbagai pelosok Indonesia masih dianggap sebagai mahluk aneh yang mengancam kehidupan sekitar sehingga layak untuk dikucilkan. Orang tidak mau terbuka mengalami gangguan mental untuk mencari pertolongan karena takut akan dikucilkan.

Hal tersebut membuat banyak orang yang mengalami gangguan kesehatan di Indonesia enggan berbicara serta terbuka mengenai gangguan kesehatan mental yang mereka alami, karena mereka tidak ingin diremehkan oleh masyarakat Indonesia. Selain itu, hal tersebut membuat orang yang mengalami gangguan kesehatan mental menarik diri dari orang-orang maupun kegiatan bersosial lainnya karena mereka beranggapan bahwa jika mereka terbuka mengenai apa yang mereka alami, masyarakat Indonesia belum begitu mengerti mengenai gangguan kesehatan mental.
Kondisi mental yang sehat pada tiap individu tidaklah dapat disamaratakan(dewi, 2012). Kondisi tersebut bisa dipengaruhi perubahan yang terjadi pada lingkungan sekitar. Kondisi inilah yang semakin membuat urgensi pembahasan kesehatan mental yang mengarah pada bagaimana memberdayakan individu, keluarga, maupun komunitas untuk mampu menemukan, menjaga, dan mengoptimalkan kondisi sehat mentalnya dalam menghadapi kehidupan sehari-hari. Penting mengajarkan tentang konsep Kesehatan mental kepada masyarakat terutama kaum muda agar mendapatkan pemahan yang tepat.

Berdasarkan paparan di atas, maka muncul ide untuk melakukan kegiatan pengabdian kepada masyarakat dengan Kampanye Edukasi tentang kesehatan mental. Kegiataan Pengabdian Masyarakat ini merupakan Kerjasama antara dosen dan mahasiswa sebagai sebuah kegiatan dalam mata kuliah Capstone di Program Studi Ilmu Komunikasi FISIP UPH. Kegiatan kampanye edukasi dipilih karena sesuai dengan dengan kemampuan yang dimiliki, dan dengan teori serta konsep pada Ilmu Komunikasi sehingga dipilih tema Pengamdian Kepada Masyarakat yaitu "Kampanye Edukasi Kesehatan Mental di Masa Pandemi Covid-19". Tujuan kegiatan ini untuk meningkatkan kesadaran mengenai kesehatan mental, khususnya kepada mahasiswa/i yang berusia 18-23 tahun yang berada di Jabodetabek yang mungkin belum begitu mengerti hal-hal yang berkaitan dengan kesehatan mental. Edukasi kesehatan mental tersebut akan dilakukan melalui pembuatan konten di media sosial Instagram dan Webinar yang akan dilakukan bersama dengan mitra yang telah dipilih sebagai narasumber. Dengan adanya kampanye edukasi kesehatan mental ini, diharapkan mahasiswa/i yang berusia 18-23 tahun yang berada di Jabodetabek dapat menerima informasi yang bermanfaat, bahkan secara terbuka jika mengalami masalah mau mencari pertolongan.

Kampanye secara virtual dipilih karena beradaptasi dengan situasi di masa pandemi Covid19, agar tetap bisa membagikan hal positif kepada masyarakat dengan mengikuti protocol Kesehatan. Daud dan Aprilani (dalam Khoerunnisa, dkk 2018:2) mengatakan bahwa kampanye bertujuan untuk mensosialisasikan suatu program, aktivitas dan informasi tertentu; memperkenalkan sesuatu; Pendidikan 851 
meningkatkan kesadaran dan mencari dukungan publik serta untuk mempengaruhi dan membujuk publik. Komunikasi dalam kampanye membentuk sebuah kegiatan yang dilaksanakan dengan konsisten pada suatu kelompok masyarakat. Hal tersebut dapat menciptakan perubahan pada sikap, opini, persepsi atau mental publik dalam pelaksanaan kampanye.

Pengertian secara umum istilah kampanye yang dikenal sejak tahun 1940- an, kampanye secara umum menampilkan suatu kegiatan yang bertitik tolak untuk membujuk (Venus, 2004 pada Misnawati 2013). Konsep kampanye yang lahir yakni melakukan kegiatan komunikasi secara terencana yang lebih moderat, terbuka, toleran, dengan waktu terbatas atau jangka pendek, dan program yang jelas, persuasif serta dapat diidentifikasikan secara jelas narasumbernya dan selalu berkonotasi positif. Kegiatan Kampanye dilakukan selama kurun waktu 3 bulan dari Mei - Juli 2020.

Kegiatan kampanye yang dilakukan paling tidak bisa membuka wawasan baru bagi masyarakat khususnya generasi muda terkait isu Kesehatan mental terutama di masa Pandemi Covid-19. Rogers dan Storey (Misnawati, 2013) menyebutkan kampanye merupakan serangkaian tindakan komunikasi yang terencana dengan tujuan menciptakan efek tertentu pada sejumlah besar khalayak yang dilakukan secara berkelanjutan pada kurun waktu tertentu. Kegiatan ini dilakukan dengan perencanaan yang matang.

Komunikator membutuhkan teknik komunikasi yang dapat mempengaruhi publik dalam menjalankan kampanye dengan baik. Salah satu teknik komunikasinya adalah PR yang dapat menciptakan kampanye menjadi kampanye Public Relations. Ruslan (2000:60 dalam Khoerunnisa, dkk 2018:2) menjelaskan bahwa kampanye PR bertujuan untuk meningkatkan kesadaran dan pengetahuan serta meningkatkan perhatian \& persepsi yang positif, sehingga terbentuk citra baik dari publik pada suatu lembaga. Dengan demikian, kampanye PR dapat dilakukan dengan memberikan motivasi, inspirasi dan mengerti pada masyarakat demi mendapatkan citra dan reputasi baik terutama terkait tema Kesehatan Mental. Kampanye merupakan sebuah upaya yang dikelola oleh satu kelompok (agen perubahan) yang ditujukan untuk mempersuasi target sasaran agar bisa menerima, memodifikasi atau membuang ide, sikap dan perilaku tertentu (Kotler \& Roberto dalam Misnawati, 2013).

Kampanye Kesehatan mental juga menjalankan fungsi komunikasi sebagai komunikasi sosial. Komunikasi tersebut menciptakan relasi yang mengandung unsur kebaikan ketika masyarakat membangun opini positif dalam situasi apa pun. Fenomena ini berhubungan dengan pendapat Harahap (2019:4-5) bahwa komunikasi sosial memiliki tujuan untuk memperoleh kebahagiaan yang terhindar dari tekanan dan ketegangan melalui tiga syarat, antara lain: 1) Konsep diri adalah pandangan mengenai diri sendiri yang hanya bisa didapatkan melalui informasi yang diberikan dari orang lain. Informasi itu menyangkut ikatan emosional dari keluarga, seperti orang tua, saudara dan orang lain yang tinggal di dalam satu rumah. Contohnya yaitu orang dapat merasa cerdas, tampan dan dicintai ketika orang lain mengatakan hal tersebut, sehingga orang itu tidak hanya mengetahui siapa dia, melainkan juga bisa merasakan konsep dirinya. 2) Eksistensi diri adalah pandangan tentang orang berkomunikasi dengan tujuannya untuk menunjukkan diri itu eksis (ada). 3) Kelangsungan hidup adalah pandangan bahwa manusia tidak bisa hidup sendiri untuk mempertahankan hidup, memenuhi kebutuhan biologis (makan \& minum) serta psikologis (sukses \& bahagia). Kegiatan Kampanye yang akan dilakukan merupakan kampanye sosial sebagai bagian dari komunikasi sosial untuk membantu masyarakat terutama generasi muda yang sangat rentan terhadap masalah gangguan mental agar bisa mengembangkan konsep diri yang baik.

Selain itu, Kampanye dilakukan untuk mengedukasi atau mendidik masyarakat untuk memiliki pengetahuan sehingga bisa mengubah perilaku kearah yang lebih baik. Ini merupakan peran komunikasi instrumental. Menurut Harahap (2019:7-8), komunikasi instrumental adalah komunikasi yang memiliki tujuan untuk menginformasikan, mengajar, mendorong, mengubah sikap, menggerakkan tindakan dan menghibur. Proses komunikasi dapat memenuhi kebutuhan pribadi dan pekerjaan, seperti mengeluarkan rasa empati, memberikan ujian atau kesan yang baik. Dengan demikian, komunikasi

$$
\text { Pendidikan }
$$


dapat mewujudkan hubungan menjadi lebih dekat atau jauh terhadap orang lain. Harapannya dengan kampanye lewat webinar dan media sosial maka setiap peserta, khalayak khususnya kaum muda bisa menemukan kenalan baru yang bisa sama-sama saling mengisi pada saat mendapatkan maslaah atau merasa diri mengalami gangguan mental. Orang tersebut yang baru dikenal lewat media sosial atau webinar bisa menjadi orang dekat yang bisa menolong atau memberikan jalan keluar.

Kegiatan Kampanye Edukasi Kesehatan Mental merupakan bagian dari kegiatan mahasiswa bekerja sama dengan dosen dalam sebuah kegiatan pengabdian masyarakat yang dikemas lewat mata kuliah Capstone sebagai mata kuliah wajib bagi mahasiswa semester akhir sebelum Tugas Akhir. Disini setiap mahasiswa yang bekerja dalam kampanye ini mengaplikasikan komunikasi sebagai ilmu. Rustan (2017:3) berpendapat bahwa komunikasi sebagai ilmu yang mengajarkan pengetahuan dan keterampilan dengan berbagai konsentrasi, seperti jurnalis, Public Relations (PR) officer, ahli manajemen komunikasi, politisi, ulama, ilmuwan, diplomat, presenter radio dan TV, dsb. Orang yang memiliki keahlian cenderung berperan sebagai komunikator yang menyampaikan pesan terhadap audiens (komunikan) pada konten tertentu. Hal tersebut dapat ditemukan di sesi seminar, kampanye dan juga penelitian dengan tujuannya untuk meningkatkan wawasan mengenai suatu tema terhadap target audiens yang telah ditetapkan. Sehingga mahasiswa yang terlibat dalam project ini mendapatkan kesempatan untuk mengembangkan diri untuk melakukan kegiatan positif bagi masyarakat luas.

Solusi yang ditawarkan adalah melaksanakan kegiatan kampanye untuk mengedukasi pentingnya menjaga kesehatan mental yang dialami oleh setiap orang dalam situasi pandemi Covid-19. Alasan memilih kampanye edukasi kesehatan mental karena proses menjalankan kampanye dilakukan berdasarkan fungsi komunikasi sebagai komunikasi sosial, komunikasi instrumental dan ilmu. Selain itu, kegiatan ini berhubungan dengan kampanye PR yang dapat mengkomunikasikan kepada publik dengan meningkatkan kesadaran mengenai kesehatan mental itu mempengaruhi situasi pandemi Covid-19 yang sedang dihadapi oleh semua orang.

\section{METODE}

Dalam menghadapi masalah kesehatan mental di Jabodetabek, kampanye edukasi Kesehatan mental di masa pandemic Covid-19, tujuannya untuk mengedukasi mahasiswa \& pekerja khususnya area Jabodetabek yang mengalami masalah gangguan mental seperti rasa cemas, takut, panik dll. Untuk mendukung hal tersebut ada dua metode yang digunakan yaitu 1) Kampanye dengan menyelenggarakan Webinar bertema "Mental Health in Pandemic Covid-19", dengan target audiens usia 18 - 23 tahun terutama mahasiswa terutama yang tinggal di area Jabodetabek, tapi tidak menutup kemungkinan peserta di luar area tersebut. Metode kampanye yang kedua adalah lewat media sosial Instagram @ healthymind_id. Kampanye pada sosial media Instagram terbagi menjadi 2 bentuk, yaitu: 1) Posting rutin konten mengenai kesehatan mental, Setiap post di Instagram akan diberikan hashtag seperti \#mentalawareness, \#mentalhealthmatters \& \#healthymind, 2) Live IG membahas tema "Good Communication makes Good Relationship”.

\section{HASIL DAN PEMBAHASAN}

Berikut adalah hasil dan pembahasan dari Kampanye Edukasi Kesehatan Mental di Masa Pandemi Covid-19.

\section{Kampanye Sosial Media.}

Kegiatan kampanye lewat media Instagram dimulai dari pembuatan istagram @healthy_mind pada 30 Mei 2020. Kampanye ini dilakukan hanya di Instagram dengan membuat akun baru yaitu @ healthymind_id. Akun ini juga telah memiliki logo resmi sebagai berikut:

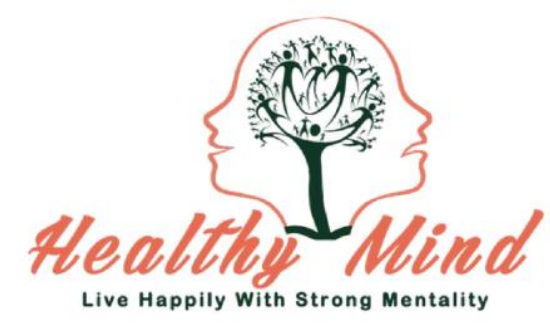

Gambar 2. Logo IG @ heatthymind_id. 
Makna dari logo tersebut adalah 1) Gambar muka senyum sebelah kiri menggambarkan Bahagia yang ditampilkan ke orang lain, gambar muka murung di sebelah kanan merupakan gambaran sedih yang dirasakan sesungguhnya tanpa diketahui oleh orang lain, makna ini memiliki arti yaitu banyak orang di sekeliling kita yang sesungguh memiliki gangguan pada mental mereka tetapi tidak terlihat oleh kita secara langsung. 2) Pohon yang terdiri dari manusia yang berhubungan (otak dan pemikiran), pohon utama berbentuk orang yang paling besar merupakan dirinya yang memiliki hubungan sosial baik dengan keluarga dan kerabat ataupun dengan teman dan sahabat yang digambarkan dalam bentuk orang yang berhubungan namun dengan ukuran yang lebih kecil dari yang utama.

Kampanye pada media sosial Instagram terbagi menjadi 2 bentuk, yaitu: 1) Posting konten mengenai kesehatan mental tentang definisi kesehatan mental, penyebab terjadi masalah mental, masalah mentang yang mempengaruhi hubungan dengan orang lain, sampai menangani masalah kesehatan mental, 2) Live bersama narasumber mengenai kesehatan mental. Live ini dilakukan pada@ @ealthymind_id melalui IGTV dengan tema "Good Communication makes Good Relationship”.

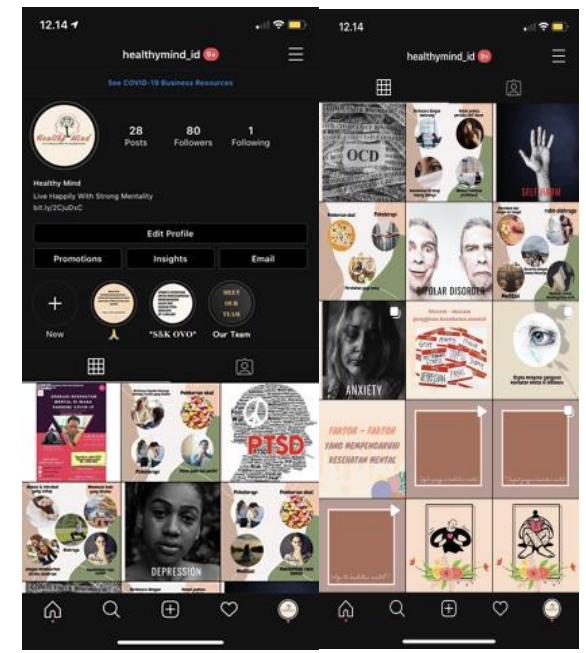

Gambar 3. Tampilan IG @ healthymind_id

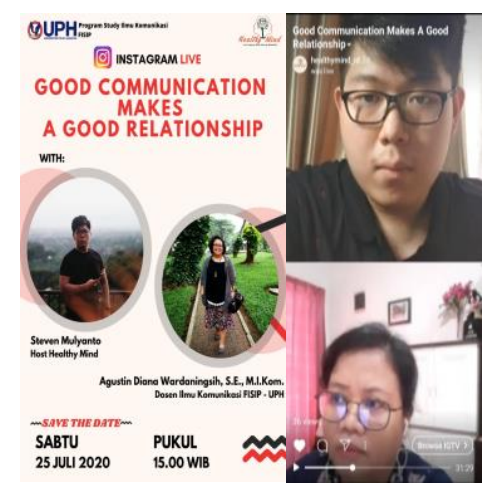

Gambar 4. Live IGTV @ healthymind_id

Tema IGTV Live dengan tema "Good Communication Makes A Good Relationship" membahas beragam pola komunikasi yang terjadi antar anak dan orang tua, hubungan pertemanan, terutama di masa pandemic Covid -19, hingga kesalahan dalam komunikasi yang bisa menimbulkan konflik. Dengan bisa berkomunikasi dengan baik, hubungan bisa terjalin dan bisa membantu mengatasi gangguan mental dengan menumbuhkan keberanian untuk bercerita dan mencari pertolongan.Masalah mental mempengaruhi hubungan pada orang lain.

\section{Webinar bertema "Edukasi Kesehatan Mental di Masa Pandemi Covid-19”.}

Webinar ini diselenggarakan pada tanggal 18 Juli 2020 dengan tema 'Edukasi Kesehatan Mental di Masa Pandemi Covid-19. Webinar ini bekerjasama mengundang founder sehatmental.id yaitu bapak Ade Binarko. Materi singkat dari webinar ini adalah setiap orang perlu mencoba lakukan hal baru \& perlu disyukuri dalam masa pandemi Covid-19. Tahap awalnya adalah perlu mencari tahu manakah yang suka dan tidak suka dalam menjalankan aktivitas. Hal ini berhubungan dengan self-acceptance yang bisa menerima diri sendiri secara fisik dan juga selflove, seperti olahraga, tidak larut tidur dan berani speak-up ketika orang mempunyai masalah mental. Lingkungan juga berdampak pada kualitas kesehatan mental seseorang yang bisa menjadi baik apabila berkumpul bersama dengan teman \& lingkungan baik, demikian juga sebaliknya. 


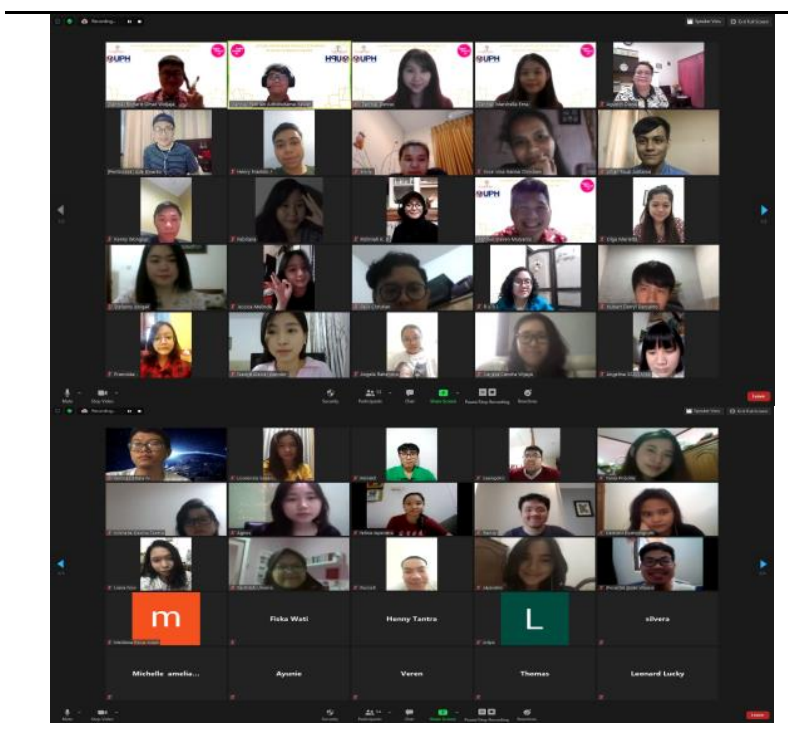

Gambar 5. Pelaksanaan Webinar Edukasi Kesehatan Mental di Masa Pandemi Covid-19

Dari target peserta sebanyak 100 orang, ternyata peserta yang mendaftar mencapai 139 orang yang berasal bukan hanya dari Jabodetabek tetapi juga dari Yogyakarta dan daerah lainnya. Beragam pertanyaan disampaikan peserta untuk memperjelas, menjawab keraguan, termasuk dalam webinar juga berhasil membuat salah satu peserta berani mengaku bahwa sudah pernah menyakiti diri sendiri karena depresi tetapi tidak pernah berani bercerita dan mencari pertolongan.

Sullivan dalam Rohimah (2009) menjelaskan perubahan perilaku dari sisi masyarakat sebagai dari kampanye sosial. Terdapat enam tahap yaitu 1) Belum tahu : tidak sadar akan adanya masalah atau resiko pribadi bagi mereka. Hal ini tergambar dari pertanyaan salah satu peserta terkait Kesehatan mental di masa Pandemi Covid-19 tentang apakah terkurung di rumah saja keluarga bisa menyebabkan stress dan menimbulkan kecemasan yang tinggi. 2) Tahu secara sadar akan adanya masalah dan mengetahui perilaku yang diinginkan, bahwa ada peserta webinar yang bercerita tentang gangguan mental yang dihadapi selama Pandemi Covid karena terkekang dan tidak berinteraksi di luar rumah. 3) setuju dengan perilaku yang diinginkan, disini saat peserta menyatakan bahwa webinar sebagai bagian dari kampanye edukasi mentas penting dilakukan karena peserta mendapatkan informasi positif dengan keikutsertaanya. 4) Berminat, bermaksud secara pribadi melakukan tindakan yaitu dari adanya beberapa peserta yang meminta saran dan arahan agar bisa mendapatkan eprtolongan yang tepat. 5 . Praktik : melakukan perilaku yang diinginkan 6 . Mengadvokasi : mempraktikan perilaku yang diinginkan sekaligus memberitahukannya kepada orang lain. Kegiatan webinar baru bisa menjadi kampanye sosial pada tahapan ke 4 sampai membuat peserta menunjukkan minat untuk bertindak, dan berubah, keluar dari masalah gangguan mental yang dihadapi.

Hasil yang didapatkan dari kegiatan webinar adalah menghasilkan dampak besar pada beberapa peserta yang berani menceritakan masalah pengalaman hidup (speak-up). Situasi ini menunjukkan bahwa peserta webinar mendapatkan efek positif dan inspirasi yang memotivasi peserta untuk berani membicarakan masalah pribadi dalam webinar.

Dari kegiatan Kampanye Edukasi Kesehatan Mental yang dimulai dari Mei hingga Juli 2020, baik lewat kegiatan kampanye di Instagram @ healthymind_id, baik postingan berkala serta live IGTV, serta Webinar yang dilakukan telah mengajarkan terutama follower IG dan peserta Webinar untuk memiliki kesadaran tinggi terkait masalah Kesehatan mental. Untuk saat ini kegiatan kampanye telah selesai, tetapi bukan berarti kegiatan ini tidak bisa diteruskan kembali. Justru dengan telah memiliki media sosial @ healthymind_id, membuka kesempatan untuk merencanakan kembali, merumuskan konsep-konsep baru untuk kembali mengadakan kegiatan serupa yang bisa diteruskan bukan hanya nantinya selama pandemic Covid-19, tetapi keberlanjutannya untuk mengedukasi secara terus menerus masyarakat terhadap us

\section{KESIMPULAN}

Kesehatan mental menjadi hal yang penting untuk dijaga agar setiap orang bisa beradaptasi dengan baik dalam berbagai situasi atau keadaan lingkungan. Gangguan mental sekecil apapun penting untuk diperhatikan dan dicari jalan keluarnya. Salah satunya dengan peka terhadap perkembangan diri sendiri, dan juga tetpa menjalin komunikasi yang baik dengan orang sekitar. Mau terbuka, berusaha 
mencari jalan terbaik, dan mencari pertolongan yang tepat, menjadi satu langkah untuk bisa mengatasi gangguan mental ini. Meningkatkan kesadaran pada isu kesehatan mental dengan memberikan edukasi kesehatan mental kepada mahasiswa/i usia 18-23 tahun yang berada di Jabodetabek melalui konten media sosial di Instagram dan Webinar ternyata bisa dilakukan di masa Pandemi Covid-19 ini, bahkan bisa dilanjutkan Kembali. Tujuan kegiatan sudah cukup tercapai dengan positif respon, salah satunya dengan memberikan manfaat sehingga seseorang berani berbicara tentang masalah kesehatan mentalnya selama. Kegiatan ini sedikit banyak juga memberikan pandangan baru bagi orang-orang yang masih awam tentang kesehatan mental dan memiliki stigma negatif kepada penderita gangguan kesehatan mental.

\section{UCAPAN TERIMAKASIH}

Segala Puji dan Kemuliaan serta ucapan terimakasih ditujukan bagi Tuhan yang telah memampukan seluruh Tim untuk menyelesaikan proses PKM ini. Secara khusus, Tim PKM juga mengucapkan terimakasi kepada :

1. Panitia PKM dan Dosen Mata Kuliah Capstone Ilmu Komunikasi FISIP UPH.

2. LPPM UPH, Dekan FISIP Naniek N. Setijadi, Kaprodi Ilmu Komunikasi Marsefio Luhukay, seluruh rekan dosen dan administrasi yang membantu dalam melaksanakan PKM ini,

3. Tim mahasiswa yaitu Febrian Irawan, Steven Mulyanto, Denise, tanpa kerja keras kalian maka tulisan ini tidak akan pernah ada.

\section{REFERENSI}

Kevin, Adrian. 2018. Sakit Jiwa Ternyata Ada Banyak. https://www.alodokter.com/sakitjiwa-ternyata-ada-banyak (diakses pada 29 Mei 2020)

Dewi, Kartika Sari. 2012. Buku Ajar: KESEHATAN MENTAL. Cetakan pertama. Semarang: Universitas Diponegoro. http://eprints.undip.ac.id/38840/1/KESEHA
TAN_MENTAL.pdf (diakses pada $29 \mathrm{Mei}$ 2020)

Florencia, Gabriella. 2020. 4 Gangguan Mental yang Terjadi Tanpa Disadari. https://www.halodoc.com/artikel/4gangguan-mental-yang-terjadi-tanpadisadari (diakses pada 29 Mei 2020)

Harahap, R.A. dan Putra, F.E. 2019. Buku Ajar Komunikasi Kesehatan. Cetakan ke-1. Rawamangun: PRENADA MEDIA GROUP http://repository.uinsu.ac.id/8240/1/Buku\% 20Ajar\%20Komunilasi\%20Kesehatanok.pdf

Khoerunnisa, R., dkk. 2018. Aktivitas Kampanye Public Relations dalam Mensosialisasikan Internet Sehat dan Aman. Jurnal Ilmu Hubungan Masyarakat. Vol. 3 No. 4, 79-96. Bandung: UIN Sunan Gunung Djati. http://jurnal.fdk.uinsgd.ac.id/index.php/repu tation/article/view/453/96

Nadhira, Andi Marsa. 2020. Menjaga Kesehatan Mental Saat Pandemi Virus Corona. https://www.alodokter.com/menjagakesehatan-mental-saat-pandemi-viruscorona

Nasution, Rifan Eka Putra. 2020. Pandemi dan Penurunan Kesehatan Mental. https://news.detik.com/kolom/d4997109/pandemi-dan-penurunankesehatan-mental. (diakses pada $29 \mathrm{Mei}$ 2020).

Putri, Adisti Wismani. Budhi Wibhawa. Arie Surya Gutama. Kesehatan Mental Masyarakat Indonesia (Pengetahuan dan Keterbukaan Masyarakat Terhadap Gangguan Kesehatan Mental. Prosiding KS Riset \& PKM. Volume 2. Hal 147 - 300. ISSN 2442-4480, 2015.

Rustan, A.S. dan Hakki, N. 2017. Pengantar Ilmu Komunikasi. Cetakan pertama. Yogyakarta: DEEPUBLISH https://books.google.co.id/books?id=Ezk2D

$$
\text { Pendidikan } \quad 856
$$


wAAQBAJ\&pg=PA2\&dq=komunikasi+seb agai+ilmu\&hl=en\&sa $=X \& v e d=0$ ahUKEwi akJCBzLpAhXE7HMBHSc_A8EQ6AEIVDAE\#v $=$ onepage $\& \mathrm{q}=$ komunikasi $\% 20$ sebagai $\% 20 \mathrm{il}$ $\mathrm{mu} \& \mathrm{f}=$ false

Rohimah, Tri Hastuti Nur. Evaluasi Pelaksanaan Kampanye Sosial Perilaku Hidup Bersih dan Sehat untuk Menurunkan Angka Diare di Kabupaten Kulonprogo. Jurnal Komunikasi. Volume $6 \quad$ No. $\quad 1.2009$. http://ojs.uajy.ac.id/index.php/jik/article/vie $\underline{w} / 207$ 